\title{
Horizontalidade dos Direitos Fundamentais e Reprodução Humana Assistida Um Novo Paradigma Contratual ${ }^{1}$
}

\author{
Janaína Reckziegel \\ Doutora em Direitos Fundamentais e Novos Direitos \\ pela Universidade Estácio de Sá - RJ. Mestre em Direito \\ Público. Especialista em "Mercado de trabalho e exercício \\ do magistério em preparação para a Magistratura" e em \\ "Educação e docência no ensino superior". Graduada em \\ Ciências Jurídicas e Sociais pela Universidade do Oeste \\ de Santa Catarina. Advogada, professora Universitária e \\ pesquisadora do Programa de Pós-Graduação em Direito \\ da Universidade do Oeste de Santa Catarina - Unoesc. \\ Editora de Seção da Revista Espaço Jurídico Journal of \\ Law da Editora Unoesc (Qualis A2). janaina.reck@gmail. \\ com. lattes: <http://lattes.cnpq.br/7597547217990217>.
}

\section{Jhonatan Felipe Laurindo Gomes Duarte}

Doutorando em Direito pela Universidad Nacional de Córdoba - AR. Mestre em Direito pelo Programa de Pós-Graduação em Direito da Universidade do Oeste de Santa Catarina - Unoesc. Advogado. Graduado em Direito pela Faculdade de Ciências Sociais Aplicadas de Cascavel Univel. jhonatann_duarte@hotmail.com. lattes: <http:// lattes.cnpq.br/6183369838762264>.

${ }^{1}$ O presente trabalho é resultado do Grupo de Pesquisa Direitos Fundamentais Civis/Sociais do Programa de Mestrado em Direito da Universidade do Oeste de Santa Catarina - Unoesc. 


\title{
Resumo
}

A teoria da Horizontalidade dos Direitos Fundamentais, surgida a partir do cenário pós-Segunda Guerra, é de inegável importância no plano jusfundamental. Responsável pela nova leitura das relações entre particulares, tal teoria confere aplicabilidade aos direitos fundamentais entre os particulares, deixando de restringir tal construção de garantias constitucionais apenas ao plano vertical, mormente expresso pela relação entre Estado e indivíduo. As práticas de Reprodução Humana Assistida englobam uma série de vetores essencialmente constitucionais dentro de seus instrumentos contratuais, com sólidas discussões acerca da autonomia privada, intimidade e dignidade da pessoa humana, com a horizontalidade jusfundamental desvelando uma nova forma de discussão de tais técnicas reprodutivas contratuais. Assim, o objeto deste estudo é a correlação entre o processo de reprodução assistida e a noção de direitos fundamentais horizontais, com fulcro essencialmente na pesquisa bibliográfica e no levantamento de dados acerca de tal problemática, apontando para novas modalidades contratuais cingidas pela teoria jusfundamental aludida.

Palavras-chave: Reprodução Humana Assistida. Horizontalidade dos direitos fundamentais. Direitos fundamentais. Teoria Geral dos Contratos.

\section{Fundamental Rights Horizontality and Assisted Human Reproduction: a new contractual paradigm}

\begin{abstract}
The Fundamental Rights Horizontality's Theory, raised in the post-Second War scenario, is from an undeniable importance in the fundamental rights field. Responsible for the new reading of the relations between private people, such theory gives applicability to the fundamental rights among privates, leaving the construction of those constitutional guaranties on vertical plan only, being this vertical relation expressed by the link between State and individual. The practices of Assisted Human Reproduction embrace a series of vectors essentially constitutional inside its own contractual instruments, with several discussions inside the private autonomy, intimacy and human dignity, with the fundamental rights horizontality revealing a new way of discussion of such contractual reproductive techniques. This way, the object of this study is the correlation between the process of assisted reproduction and the notion of horizontal fundamental rights, with bias essentially on bibliographical research and the raising of data inside such problematic, pointing to new contractual modalities girted by the fundamental rights theory pointed above.
\end{abstract}

Keywords: Human assisted reproduction. Fundamental rights horizontality. Fundamental rights. Contract's theory.

\section{Sumário}

1 Introdução. 2 Reprodução Humana Assistida. 3 Horizontalidade dos Direitos Fundamentais. 4 Horizontalização dos Direitos Fundamentais e a Reprodução Humana Assistida. 5 Considerações Finais. 6 Referências 


\section{INTRODUÇÃO}

A Reprodução Humana Assistida, como já esperado, trouxe consigo uma série de vetores bioéticos, que emergem numa série de conflitos jurídicos já detalhados pela literatura especializada. A possibilidade de controlar a própria reprodução da espécie é matéria controvertida por razões que extrapolam a religião e o mero senso comum arraigado: é questão ética de observância elementar.

O paradoxo ético - e jurídico - da Reprodução Humana Assistida, como não poderia deixar de ser, vai ao imediato encontro da teoria já solidificada dos direitos fundamentais; garantias constitucionais positivadas ou naturais agora passam ao centro das atenções graças à postura judicial esperada em detrimento das inúmeras possibilidades que o caso concreto apresenta sem cessar, numa clara demonstração de que o poder Judiciário apresenta sua face ativista também nos quadros de reprodução assistida.

A horizontalização dos direitos fundamentais - teoria que passa a ganhar força após o advento da Segunda Guerra Mundial - cuida de estabelecer a série de nuances éticas e jurídicas que a Reprodução Humana Assistida avoca. A inafastável necessidade de respeito aos direitos fundamentais, agora no plano entre particulares, traz uma série de possibilidades jurídicas sobre as quais o presente estudo repousa. A questão que funda o corrente estudo passa a ser, então, sobre o plano de tal horizontalização nas relações contratuais oriundas da reprodução assistida apontada, e de que maneira elas mostram-se alteradas com tal advento teórico.

O direito à intimidade - estendido, aqui, também para a intimidade genética - revela diversas potencialidades de elementos e conflitos, de maneira que mais do que mero hard case exigente de eventual pondera- 
ção, a horizontalidade dos direitos fundamentais traz à baila a pertinência e alcance de tal intimidade dentro do plano contratual da reprodução assistida.

Desta forma, coligando o direito fundamental à intimidade, neste caso, genética, com a própria teoria da horizontalidade dos direitos fundamentais, tem-se uma das mais relevantes questões do Direito contemporâneo, com a sociedade atual funcionando como mais do que mero pano de fundo, mas como alimentador do próprio fato social que a atinge, com as relações jurídico-contratuais extrapolando o simples alcance volitivo, abarcando, desde já, dilemas éticos e paradoxos jurídicos, a fim de revelar a verdadeira finalidade - e limitação - dos direitos fundamentais horizontais no caso da Reprodução Humana Assistida.

\section{REPRODUÇÃO HUMANA ASSISTIDA}

O desejo de gerar descendentes, um dos mais naturais e compreensíveis dos desejos humanos, não pode ser desvinculado do processo de Reprodução Humana Assistida. O processo de filiação e formação familiar data desde os primórdios da História humana, sendo que Rouland (2003) acertadamente lança as bases de tal questão: o que nos diferencia de todos os outros animais é justamente o reconhecimento, fomento e continuidade de laços familiares com papéis institucionais integralizados.

Não obstante, a maternidade emerge, de acordo com Barbosa (2003, p. 44), como "destino social das mulheres", de maneira que mais do que expectativa de toda a sociedade em torno da geração de filhos, a gestação também acarreta - conforme abordado a seguir - um mecanismo identitário que fornece significado e contexto para as mulheres que almejam a geração de filhos; evitá-la ou não obtê-la, assim, tem um custo social e individual. 
O conceito formado por Ahmad (2009), que traz a paternidade como status pessoal, surge antes mesmo do próprio processo de historicismo da formação familiar dentro de modelos reprodutivos, de maneira que, na esmagadora maioria das vezes, a formação do núcleo familiar humano é processo de formação identitária tal qual o nascimento ou a morte.

A esterilidade, assim, traz consigo inúmeros contratempos e estigmatizações sociais, pois desde já se sabe que “[...] o desejo de procriar é antigo" (Ferraz, 2011, p. 39). Este autor (2011) aponta que o repúdio familiar era esmagador em relação às mulheres incapazes de gerar descendentes, e a possibilidade masculina de infertilidade ${ }^{2}$ não era sequer investigada. Dessa forma, a mulher sempre foi o alvo de críticas em relação a não geração de filhos, com algumas chegando até mesmo a serem abandonadas em tais casos.

Dados recentes dão conta de que disfunções causadoras de infertilidade distribuem-se à razão de $40 \%$ (quarenta por cento) entre o sexo feminino, com o mesmo número acometendo homens, com os 20\% (vinte por cento) sobressalentes sendo a combinação de circunstâncias de ambos os sexos que impossibilitam a geração de filhos (Barbosa, 2003). Não obstante, foi apenas a partir de 1677, com a invenção do microscópio por Leeuwenhoek, que as causas da infertilidade masculina começaram a ser investigadas, principalmente pela escassez de espermatozoides (Ferraz, 2011).

No seio da família, era muito comum a esterilidade provocar sua desagregação em face do sentimento de incompetência, frustração, culpa, inferioridade e angústia pelo fracasso no projeto parental, principal-

${ }^{2}$ Há unanimidade na doutrina especializada dentro da ressalva existente entre infertilidade e esterilidade: a primeira possui tratamento médico, podendo ser até mesmo curada, ao contrário da última, que é cingida pela irreversibilidade. Na esteira de Ferraz (2011) e Ahmad (2009), o corrente estudo reconhece tal diferenciação, optando pela utilização do termo infertilidade como conglobante de ambas as formas. 
mente o de perpetuação dos membros da família, quando o biologismo era tido como a única forma de concretizá-lo. Não se pode olvidar, também, as consequências para o homem e para a mulher do ponto de vista social, já que as pessoas em geral associavam a esterilidade, seja ela masculina ou feminina, à derrota e a um mal incomensurável (Ferraz, 2011, p. 41).

Uma égua, que, com o auxílio humano foi fecundada em 1332, revela-se o primeiro caso de utilização da técnica de inseminação artificial (Barbosa, 2003). Já quanto à experiência em seres humanos, Scarparo (1991) afirma que a prática de inseminação artificial ocorreu por volta de 1494, quando tal técnica foi experimentada na rainha D. Joana de Portugal, mas a tentativa resultou infrutifera. Ainda de acordo com a mesma autora, por volta de 1785 o sucesso foi alcançado por meio das técnicas de reprodução artificial em um ser humano, quando Thouret - Decano da Faculdade de Medicina de Paris - conseguiu fecundar sua própria esposa estéril.

Gregor Mendel, estipulando as bases do estudo da genética enquanto campo científico autônomo, forneceu a sedimentação necessária para o desenvolvimento da Engenharia Genética, agora capitaneada por James Dewry e Francis Harry Compton Crick, ambos tidos como pais de tal seara metodológica. A Reprodução Humana Assistida, enquanto mecanismo auxiliar para casais que possuem dificuldades de reprodução, somente começou a tomar forma com a Engenharia Genética possibilitando o desenvolvimento e evolução da Reprodução Humana Assistida, dentro de todas as modalidades hoje existentes (Ferraz, 2011).

De acordo com Leite (1995), até o século 20, a reprodução humana assistida pouco havia evoluído, pois em meados da década de 30 a literatura médica internacional tinha ciência de apenas 88 casos. Em 1945 foi descoberto que os espermatozoides submetidos a baixas temperaturas, juntamente com glicerol, tornaria possível conservá-los por longo tempo. A partir disso, as técnicas de reprodução humana assistida lograram êxito 
e, da década de 50 em diante se expandiu. No Brasil, registros datam de 7 de outubro de 1984, quando se registrou o nascimento do primeiro bebê de proveta no país. Em contrapartida, o surgimento do primeiro bebê de proveta no mundo ocorreu em 1978 (Fernandes, 2005).

Tal criança, concebida pelo método da fertilização in vitro, ou fivete, trouxe consigo uma série de críticas - influenciadas principalmente por argumentos de cunho religioso de desnecessária intervenção humana em processos reprodutivos - mas, como aponta ainda Ferraz (2011), algumas outras técnicas passaram a ser desenvolvidas com o objetivo específico de intervir o mínimo possível em tal processo reprodutivo, conforme se verá a seguir.

A inseminação artificial, técnica de enorme complexidade, foi a primeira modalidade de Reprodução Humana Assistida. Esse instrumento de reprodução funciona nos casos de falha nas etapas do processo reprodutivo, e não necessariamente nas bases celulares. O sucesso de tal técnica depende “[...] do cálculo exato da ovulação, pois o material germinativo masculino é introduzido no útero, devendo se desenvolver naturalmente a gestação” (Ferraz, 2011, p. 44).

Em 1932, quando avanços científicos deram conta de descobrir de maneira precisa o ciclo fértil feminino, a inseminação artificial passou a ser possível, e em 1945 a criopreservação do sêmen veio a colaborar com tal cenário de apoio científico reprodutivo (Ferraz, 2011). Assim, com a inserção do sêmen no interior uterino, é de se esperar que tal técnica reproduza com maior similitude o que naturalmente ocorreria, caso não houvesse falhas no ciclo de fatores da reprodução.

As formas homólogas e heterólogas de inseminação artificial são destacadas por Ferraz (2011). Na primeira forma o sêmen a ser implantado na mulher é de origem do próprio marido ou companheiro, e na última o sêmen advém de doador alheio ao processo reprodutivo. Sem prejuízo 
do exposto, vê-se ainda a inseminação artificial biosseminal, quando, para aumentar as chances de sucesso da inseminação, o sêmen é recolhido do marido e do doador, e ambos são utilizados ao mesmo tempo.

Por fim, insta ressaltar que o material genético masculino, dentro da inseminação artificial, é recolhido por masturbação e separados entre normais e anormais - distinguidos mediante a velocidade e qualidade do espermatozoide - e posteriormente imersos em líquido próprio, podendo, inclusive, ser conservados por até 20 anos pela técnica da criopreservação (Ferraz, 2011).

Continuando a análise bibliográfica sobre a fertilização in vitro, foi nela que, como já exposto, se viu a possibilidade de geração de uma vida efetivamente por intermédio do meio científico, com a ocorrência do primeiro bebê de proveta na década de 70, ressaltando a importância - e se fazendo perceber a vinculação das formas assistidas de reprodução com os ramos mais complexos da Engenharia Genética - de tal modalidade dentro dos limites evolutivos científicos, como bem assinala Hammerschmidt (2013).

Ommati (1999) estabelece tal técnica como sendo fertilização in vitro seguida de transferência de embriões, de modo que o zigoto ou os zigotos permanecem sendo incubados in vitro até que atinjam um estado de maturação suficiente para a transferência até o útero ou até as trompas. Para Ferraz (2011, p. 45), a “[...] fertilização in vitro consiste em colher óvulos de uma mulher, fertilizando-os numa placa de Petri, para, quando já transformados em zigotos, iniciando a divisão celular, serem colocados dentro do útero da receptora”.

Quatro condições indispensáveis para o sucesso do procedimento são apontadas por Weider (2007), quais sejam: a) o óvulo deve ter seu metabolismo funcionando perfeitamente; b) o óvulo deve ser penetrado pelo espermatozoide, ambos se incorporando; c) o cromossomo e o núcleo do óvulo devem estar unidos e d) devem também estar unidos o cromos- 
somo e o núcleo do espermatozoide penetrante. Da mesma forma que a inseminação artificial, a fertilização in vitro pode ser homóloga ou heteróloga, em que o material genético da mulher também pode advir de doadora, com a ocorrência possível, inclusive, de gestação no útero de terceira mulher, conhecida como maternidade de substituição (Ferraz, 2011).

Um processo de indução da ovulação por meio da inserção de hormônios femininos ocorre, ainda, na fertilização in vitro. Desta forma, a mulher tende a liberar mais óvulos, facilitando a inseminação, porém em quantidade baixa o bastante para evitar a gravidez simultânea de duas ou mais crianças. Assim, após o prazo de 36 horas de adequação dos óvulos, haverá a punção deles, com a consequente doação de material genético por parte do parceiro, ou mero recolhimento do material previamente congelado, com óvulos e espermatozoides sendo analisados e postos no mesmo meio. A verificação de eventual fertilização se dá 48 horas após o procedimento mencionado e, caso tenha ocorrido, os embriões serão inseridos no útero, com realização de teste de gravidez quatorze dias após a inserção (Ferraz, 2011).

O Gamete Intrafallopean Transfer (GIFT), ou Reprodução Humana Assistida com gametas, também funciona como mecanismo auxiliar dos genitores no processo reprodutivo dificultoso. Como explica Ferraz (2011), mediante laparoscopia óvulos da mulher são recolhidos, bem como o esperma, sendo colocados ambos numa cânula especial, preparados conforme o protocolo médico, e tal junção é introduzida em cada uma das trompas de Falópio, onde a fertilização passa a ocorrer naturalmente.

A diferença entre o Gamete Intrafallopean Transfer e a fertilização in vitro é o fato de ocorrer no interior do corpo feminino, não extracorporeamente, como a última. Assim, tal técnica exsurge como uma alternativa às fertilizações in vitro para o oferecimento de condições mais naturais 
de desenvolvimento, migração e nidação para o embrião, o que reduz o risco de gestações extrauterinas, sendo, inclusive, mais aceita pela Igreja Católica (Ferraz, 2011).

Tem-se, ainda, a penúltima técnica aplicável dentro dos moldes aludidos, enquanto variante da fertilização in vitro, a Zygote Intrafallopean Transfer (ZIFT). Nesta, os espermatozoides são postos em contato com os óvulos, fora do corpo da mulher, havendo a formação do zigoto com a fecundação. A diferença entre tal técnica e a GIFT é que “[...] nesta, a fecundação ocorre dentro do corpo da mulher, nas trompas, enquanto na técnica ZIFT, ocorre fora do corpo da mulher” (Ferraz, 2011, p. 48).

Após um ano de seguidas tentativas de fecundação natural, tal técnica é indicada, além de sê-la para casais que falharam à estimulação ovariana com inseminação intrauterina durante cinco ou seis ciclos, com a ZIFT sendo mais rápida que a GIFT, havendo menos chances, inclusive, de uma gestação múltipla (Ferraz, 2011).

Por fim, no caso de mulheres que não podem gerar um filho em decorrência de indicação médica para a não gestação - casos como a insuficiência renal grave -, ou devido à ausência de útero, tem-se a maternidade de substituição como alternativa. Conforme Ommati (1999) explicita, não se trata de uma instrumentalidade biológica, mas da simples utilização da fertilidade de outra mulher para gestação, em razão da impossibilidade física da primeira mulher. Tal técnica também é utilizada por pares homossexuais, que a vem como solução para o problema da incompatibilidade de gêneros. Nesta linha, Leite (1995, p. 36) assevera que a maternidade de substituição trata-se de um “empréstimo” do útero, ou seja, “[...] apelar a uma terceira pessoa para assegurar a gestação quando o útero materno não possibilita o desenvolvimento adequado do bebê”.

Ressalva que deve ser levantada, como bem observa Ferraz (2011, p. 49), é a possibilidade de “[...] ser feita a distinção entre mãe portadora e mãe substituta, recebendo a primeira o óvulo do casal já fecundado, 
enquanto a segunda é inseminada com o esperma do marido da solicitante, e fornece o próprio o óvulo”. Assim, a mulher que carrega o feto (primeiro caso) não vai transmitir informação genética alguma ao feto, uma vez que todo o material genético adveio dos contratantes ou de terceiro. Enquanto que no segundo caso, normalmente ocorre a fecundação de óvulo da mulher que irá ceder o ventre.

A resolução do Conselho Federal de Medicina 2.013/2.013 deixa explícita a proibição de remuneração em tais casos (Brasil, 2013). Deve-se considerar, porém, que a mãe portadora terá gastos com a gravidez, podendo-se citar: roupas, alimentação, transporte para consultas médicas e exames, bem como com o tratamento psicológico para auxiliar na relação afetiva com o feto.

Neste sentido é permitido que seja firmado um acordo financeiro, o qual deverá apenas subsidiar os gastos médicos, roupas de maternidade e outras despesas decorrentes de uma gestação, que podem incluir ainda alimentação (Cotto, 1987). Importante ressaltar que a cláusula de ajuste financeiro traz à tona a discussão sobre a possibilidade de este ajuste ser considerado uma remuneração, o que configuraria crime no Brasil, pois a comercialização de órgãos humanos é tipificada no Direito Penal brasileiro por meio do dispositivo inserto no artigo 15 da Lei 9.434, in verbis: "Comprar ou vender tecidos, órgãos ou partes do corpo humano: Pena - reclusão de 3 a 8 anos, e multa, de 200 a 360 dias-multa”. Por isso, não observa-se atualmente a gestação por outrem como contrato de prestação de serviços, mas sim como uma troca em favor do outro, motivada pela solidariedade e pela amizade (no caso de uma amiga ceder seu ventre a um casal homoafetivo masculino, por exemplo). Quando levada ao Judiciário uma situação como a exposta, pretende-se que o juiz, ao decidir, paute-se no homem médio e nas decisões mais recentes, tendo em vista as novas formações familiares e as diversas formas de instrumentação genética. 
Não existem dúvidas de que tais modalidades de implantação de material genético acarretam inúmeras discussões no plano bioético, moral e jurídico, mormente na seara dos direitos fundamentais, conforme se verá a seguir, sempre apelando à mínima regulamentação normativa para o fornecimento de respostas adequadas para os casos em tela.

\section{HORIZONTALIDADE DOS DIREITOS FUNDAMENTAIS}

Não há tema de tanto aporte no Direito quanto os direitos fundamentais. A tentativa da literatura especializada de conceituar e determinar tais axiomas data de muito antes deste século, com a notória e plausível dificuldade em circundar um tema de tamanha complexidade. Como bem apontam Dimoulis e Martins (2014), os próprios direitos fundamentais não são conhecidos apenas como direitos fundamentais, incluindo liberdades fundamentais, liberdades individuais, liberdades públicas, direitos humanos, direitos constitucionais, direitos subjetivos, entre outros.

A adoção generalizada da terminologia direitos fundamentais é explicável, ao menos no caso brasileiro, pelo fato de o próprio Texto Magno explicitá-la, em seu Título II. Cabe, contudo, salientar que a própria Constituição brasileira adotou terminologias diversas em alguns momentos, o que pode prejudicar a defesa sistemática de tais garantias, como expõem Dimoulis e Martins (2014), que lamentam a inconstância da expressão na Carta Magna. Para os autores, tal questão terminológica primordial apresenta duas facetas: a) na história constitucional global, várias expressões passaram a apresentar diversos significados; e b) a utilização de determinada terminologia pela Constituição pode oferecer argumentos pontuais e sistemáticos contra ou a favor da tutela de determinados direitos, como, verbi gratia, sugerindo a exclusão, quando na referência a direitos individuais ou liberdades fundamentais, dos direitos sociais, 
visto que parte da doutrina especializada chega a considerar os direitos sociais como subespécies dos direitos coletivos, não cabendo sua análise enquanto tipos individuais.

Nessa perspectiva, “[...] não há uma terminologia correta” (Dimoulis; Martins, 2014, p. 40) para a definição conglobante dos direitos fundamentais, devendo o estudo ser respaldado no próprio sentido que ultrapassa a mera terminologia e dá aporte à devida construção teórica. Assim, Cavalcante Filho (2015) prefere expor os direitos fundamentais unicamente com suas bases fundantes: o Estado Democrático de Direito e a Dignidade da Pessoa Humana.

Consoante o exposto, os direitos fundamentais adquirem relevo na ordem jurídica a partir do momento em que são fundados em um contexto sabidamente democrático. Passam, assim, a ser definidos como “[...] direitos público-subjetivos de pessoas (físicas ou jurídicas), contidos em dispositivos constitucionais e, portanto, que encerram caráter normativo supremo dentro do Estado, tendo como finalidade limitar o exercício do poder estatal em face da liberdade individual” (Dimoulis; Martins, 2014, p. 41).

Pfaffenseller (2007), adotando posição mais comedida, acredita na dificuldade de conceituação dos direitos fundamentais pelo fato de terem de ser colocados contra a perspectiva histórica e social que os funda. Nesse sentido, "uma das principais problemáticas dos Direitos Fundamentais é a busca de um fundamento absoluto sobre o qual respaldá-los, de modo [...] a garantir sua observância de maneira universal" (Pfaffenseller, 2007, p. 93).

Não há dúvidas de que toda a tentativa de erigir um conceito e um pano de fundo para os direitos fundamentais serve exclusivamente para garantir sua defesa e sua efetividade, constituindo tais garantias elementares verdadeiras preocupações sociais, filosóficas e, obviamente, essencialmente jurídicas (Pfaffenseller, 2007). Noutra senda, Maia (2008) lança mão 
do critério objetivo quanto aos direitos fundamentais, reconhecendo-os como vantagens prescritas na Carta Magna, mas não vendo razão para não crer na verticalização dos direitos fundamentais, sendo o único problema sua horizontalização.

O autor observa que tal horizontalização dos direitos fundamentais também é conhecida como eficácia externa ou privada dos direitos fundamentais, surgindo em oposição à óbvia relação Estado-indivíduo, em que o ente supraindividual deve obedecer de maneira incontinenti o constitucionalmente resguardado na tratativa para com o sujeito, sendo a questão agora a eficácia de tais liberdades intersubjetivas dentro da esfera entre particulares (Maia, 2008). É graças à eficácia direta ou imediata que emana dos direitos fundamentais que tal exigibilidade horizontal pode ser levada a cabo, tendo Canaris (2003) observado o fato de a relação Constituição-particular ser o grande problema da teoria constitucional deste século.

Nenhum outro ramo do Direito é tão atingido pela horizontalização quanto o Direito Civil. Neste sentido, aponta Maia (2008) que a tendência de tal horizontalização dos direitos fundamentais gerou o surgimento de um Direito Civil constitucionalizado, também conhecido tal movimento como a publicização do Direito Privado, ou até mesmo a privatização do Direito Público, evocando uma profunda modificação estrutural no Direito Civil, que passa a se inter-relacionar profundamente com o Direito Constitucional, fazendo com que o ramo civilista procure um constante ponto de partida na Constituição.

Não há dúvidas que tal “[...] vinculação de sujeitos de direito além do Estado" (Dimoulis; Martins, 2014, p. 103) traz em seu bojo uma série de nuances vislumbráveis dentro do pano de fundo constitucional. $\mathrm{O}$ primeiro de tais vetores é quanto à aplicabilidade dos direitos fundamentais em relações horizontais, tão logo, num primeiro momento, a horizontalidade 
jusfundamental foi percebida apenas no âmbito direto, ou seja, com todas as normas constitucionais revestidas de aplicabilidade imediata entre particulares.

Dimoulis e Martins (2014) trazem o fato de que o Direito passou a reconhecer, posteriormente, o efeito horizontal indireto, com aplicabilidade mediata dos direitos fundamentais na seara privada. Assim, dentro do Ausstrahlungswirkung, o efeito de irradiação dos direitos fundamentais horizontais, "o problema que se apresenta é saber como se manifesta o efeito horizontal nos casos concretos [...]" (Dimoulis; Martins, 2014, p. 104).

A resposta, apesar de objetiva, não é simples. Vislumbrar a aplicabilidade horizontal dos direitos fundamentais exsurge da análise das circunstâncias fáticas, dado que o elemento indispensável para tal aplicação “[...] não é uma desigualdade geral e de cunho material (ricos vs. pobres, empregados $v s$. empregadores, empresas $v s$. consumidores etc.)” (Dimoulis; Martins, 2014, p. 106), mas, sim, uma diferenciação desigual de posições no cerne da relação jurídica analisada - e comprovada - no caso concreto.

\section{A HORIZONTALIZAÇÃO DOS DIREITOS FUNDAMENTAIS E A REPRODUÇÃO HUMANA ASSISTIDA}

Dentro do panorama exposto dos direitos fundamentais adquirindo máximo relevo dentro das relações entre particulares, parece assistir razão a Petterle (2007) quando vislumbra os direitos fundamentais que mais correm riscos neste caso: a intimidade e a identidade genética. Hammerschmidt (2013), neste mesmo sentido, vê a intimidade genética como direito personalíssimo e em verdadeiro risco no caso apontado. Sem embargo, merece conceituação a vida como aspecto de formação do processo reprodutivo assistido, previamente à própria análise da identidade. 
Decorrente da própria circunstância de se pertencer à espécie humana, o direito à vida, como construção de ordem predominantemente natural-moral, constitui-se como elemento inicial e indissociável de todo o rol de direitos fundamentais, revestido, como não poderia deixar de ser, de todo o caráter absoluto e imperativo desta série de garantias. A construção da garantia à vida é exposta por Massini (2008, p. 89, tradução nossa, grifos do autor) “[...] também chamado de direito de não ser morto, ou de inviolabilidade da vida, [é] a base e a condição necessária para a existência de todos os direitos humanos", ${ }^{3}$ que em seguida volta ao plano da identidade e sua funcionalidade social.

A partir do espectro da identidade como ferramenta eminentemente social, expõem Fraser e Lima (2012, p. 364, grifo nosso) que “[...] a identidade é um instrumento fundamental para a individualização social e jurídica do ser humano, e que pode ser compreendida como a projeção pública de sua personalidade”. A questão genética passa a ser, assim, quanto às garantias de se permanecer como indivíduo irrepetível em todos os planos identitários, iniciando quanto à própria ascendência biológica.

No âmbito dos contratos clínicos erigidos em torno da relação jurídica que versa acerca da Reprodução Humana Assistida, a horizontalização dos direitos fundamentais, dentro dos critérios direto e indireto já destacados por Dimoulis e Martins (2014), é observada na manutenção do anonimato do doador e do receptor do material genético, posto que toda a relação de direito aqui apontada baseia-se na premissa elementar do anonimato.

Entendendo-se a intimidade "[...] como um direito negativo ou de proteção contra ingerências legítimas" (Hammerschmidt, 2013, p. 94, grifo da autora), não pode ser afastado o seu critério de direito fundamental,

3 “[...] también llamado derecho a no ser muerto, o a la inviolabilidad de la vida, es la base y la condición necesaria de la existencia de todos los derechos humanos”. 
pois mais do que meramente transcrito no texto constitucional, "a intimidade é um direito inerente à pessoa, que não é preciso ser conquistado para possuí-lo nem se perde por desconhecê-lo. É uma característica própria do ser humano pelo mero fato de sê-lo” (2013, p. 93, grifo nosso).

Conforme observa Agostini (2011), a situação da intimidade enquanto direito fundamental foi drasticamente alterada na ordem constituinte pós-1988. O autor expõe, ainda, que a Carta Magna de 1988, mais do que expressar literalmente a intimidade enquanto garantia do indivíduo - conforme o artigo $5^{\circ}$, inciso X da Lei Fundamental - pôs esta mesma intimidade no patamar jusfundamental de cumprimento das "[...] exigências de dignidade, de liberdade e igualdade humanas [...]” (Agostini, 2011, p. 135).

O respeito ao direito à intimidade revela-se elementar na medida em que apresenta tríplice importância: para o desenvolvimento da personalidade do indivíduo, para o aprimoramento social e para a própria sustentação de regimes pautados na democracia. Quanto a esta última, expõe Agostini (2011) que forças são voltadas contra a intimidade em regimes que não o democrático. Exemplo mais claro do exposto pelo autor é o autoritarismo, em que a privacidade é a ameaça constante ao estabelecimento governamental, tão logo a própria subsistência do regime ditatorial é ameaçada pelo não controle e manipulação da esfera íntima dos cidadãos. A utopia, não obstante, programa os cidadãos de maneira implacável, trazendo consigo a necessidade de dissolução das esferas pública e privada.

Retomando o tema do sigilo da informação genética enquanto norte da horizontalização dos direitos fundamentais no âmbito da Reprodução Humana Assistida, Petterle (2007) adverte que o direito à identidade genética - e seu sigilo - abrange o genoma de cada indivíduo, ou seja, a base biológica genética essencial e única de cada ser humano. A genética, assim, também deve ser vista pelo seu viés essencialmente humanístico, 
uma vez que "a maior parte das questões que provoca concernem tanto à vida quanto à morte, isto é, a finitude do ser humano"4 (Bergel, 2002, p. 320, tradução nossa).

Não há dúvidas, assim, de que a questão passa a ser única e exclusivamente a necessidade de se revelar a identidade do doador e/ou receptor como definição de colisão de direitos fundamentais no plano horizontal. Como tal hard case tem-se, por exemplo, o caso da necessidade premente de se revelar a identidade do doador de material genético em virtude de a criança gerada a partir de tal material doado carecer, agora, de determinada parte do corpo do progenitor. É plausível tal situação no caso de crianças com leucemia, quando a medula óssea compatível pode ser única e exclusivamente a do fornecedor de material. Diante de tal problema, urge a necessidade de percepção da horizontalidade dos direitos fundamentais, inclusive quanto à teoria da ponderação.

A resposta para os problemas que se apresentam nas circunstâncias fáticas repousam nos princípios hermenêuticos constitucionais, mormente o princípio da unidade da constituição, que se relaciona profundamente com o princípio da concordância real entre os valores expressos no texto constitucional, de modo que seja viabilizado a eficácia de ambos os axiomas, sem que seja um em detrimento do outro. Assim, o estabelecimento de limites, no caso prático, urge pela proporcionalidade, não devendo ultrapassar o necessário quando da coadunação de ambos os bens jurídicos (Petterle, 2007).

O direito à identidade dentro de tal quadro de conhecimento das origens genéticas traz à baila o fato de o conhecimento da paternidade biológica constituir um “[...] fator social imprescindível para a concretização de direitos da personalidade, pois toda pessoa humana, especialmente

4 "La mayor parte de las cuestiones que provoca conciernen tanto a la vida como a la muerte, es decir, a la finitud del ser humano". 
aquela em formação, tem direito à paternidade” (Ahmad, 2009, p. 22). Neste mesmo sentido, ponto que fortalece a identidade genética como garantia fundamental é o fato de a informação genética ser estrutural, permanecendo com “[...] o indivíduo desde o nascimento até a morte, e por isso possui características especiais que a diferenciam das outras [informações]: é involuntária, indestrutivel, permanente e singular" (Hammerschmidt, 2013, p. 90).

Não obstante, sintetiza Petterle (2007, p. 110) que “[...] a identidade genética da pessoa humana é um bem jurídico a ser preservado, enquanto uma das manifestações essenciais da personalidade humana”. Urge, assim, expor o fato de a informação genética portar a "[...] garantia de desenvolvimento e formação da individualidade” (Ahmad, 2009, p. 22), de forma que a identidade - agora compreendida como fator social de abrangência múltipla; imagem, honra e autodefinição - seja garantida pelo mais basilar fundamento: a expressão gênica.

Ipso facto, também expõe Petterle (2007, p. 113) que "como direito de defesa, o direito à identidade genética opera como uma barreira, invalidando todos os atos atentatórios à identidade genética do ser humano, independentemente da natureza pública ou privada destes atos, sejam normativos ou não”. Os principais casos apontados pela autora aludida são a função defensiva voltada a) ao conhecimento do genoma humano; b) à clonagem humana e c) a não alteração da identidade genética. Nada obsta, contudo, a análise do exposto ao caso da necessidade de revelação da identidade do doador e/ou receptor de determinado material genético, despontando também aqui a função defensiva do direito à intimidade genética.

É por não haver absolutismos constitucionais que o tema se reveste da inegável importância até então apontada. As circunstâncias concretas, assim, dão azo única e exclusivamente a sua análise dentro do panorama da ponderação, em que a horizontalidade dos direitos fundamentais reflete 
a inafastável necessidade de observar a intimidade conjugada com outros valores supremos da Constituição, quais sejam, a vida, a liberdade ou a própria dignidade de outro ser humano.

\section{CONSIDERAÇÕES FINAIS}

Não há norte axiológico nos direitos fundamentais que se compare com a dignidade da pessoa humana. A noção de humanidade como fundamento autorreferenciador do homem é o que lhe dá motivo para a observância dos mais diversos direitos fundamentais, da vida ao devido processo legal. A dignidade, assim, é o significado primeiro do próprio sentido de humanidade.

Enquanto base inafastável da construção dos direitos fundamentais, a dignidade humana assenta em si as premissas elementares do respeito a tudo que confere sedimento e relevo à identidade humana, como, de acordo com o até então exposto, o próprio direito à intimidade.

A necessidade de ser respeitado enquanto organismo único traz à baila, mais uma vez, o autorreferenciamento como medida pontual para a caracterização do sentimento de humanidade, tão logo a própria construção dos direitos fundamentais revela a indissociável noção de irrepetibilidade humana. Ser visto, assim, como organismo único, traz a noção do ser humano como fundamento elementar de toda uma ordem jurídico-constitucional.

O processo de Reprodução Humana Assistida também exsurge como paradoxo pós-moderno de contornos técnico-científicos. A possibilidade de controle sobre os próprios mecanismos de reprodução acalenta mais do que um sonho da humanidade, mas também traz consigo uma série de vetores bioéticos dos quais o direito não pode se eximir de 
posicionamentos. É dentro de tal quadro de complexidade social que os direitos fundamentais - e sua necessidade de equilíbrio - emergem como respostas lógicas.

A própria teoria da horizontalidade dos direitos fundamentais, que, como visto, adquire enorme relevo após o contexto da Segunda Guerra Mundial, demonstra a urgente necessidade de concatenação de objetivos comuns de relações privadas dentro do complexo cenário do Direito Público. O respeito - que aqui quase beira a observância obrigatória conferida pelo critério da aplicabilidade (i)mediata dos direitos fundamentais - às garantias constitucionais elementares traz à tona uma série de questionamentos sobre a validade e a ponderação de tais relações jurídicas.

O respeito ao anonimato, tanto do doador de material genético quanto de seu receptor, enquanto base para o funcionamento de tal relação essencialmente contratual, agora adquire contornos de paradoxo jusfundamental. A eventual necessidade de revelação da identidade de um ou de ambos os polos de tal relação jurídico-contratual para que outro direito fundamental seja respeitado traz à tona a relação de princípios constitucionais sistemáticos que orientam tais situações conflituosas e paradoxais. A ponderação, aqui, mais uma vez deve ser detida e em consonância com a complexidade do caso concreto apresentado.

Não há, por fim, prevalência deste ou daquele direito fundamental dentro da ordem jurídica, mas, sim, a constante lembrança da impossibilidade de absolutismos em matéria de liberdades intersubjetivas, pois o próprio quadro da Reprodução Humana Assistida emerge dentro da relativização de várias destas mesmas liberdades. O que urge, então, é a rememoração de que a ordem constitucional não prega valores imutáveis e intangíveis, mas a concatenação e o justo equilíbrio, aqui sempre analisados dentro do fulcro da ponderação. 


\section{REFERÊNCIAS}

AGOSTINI, L. C. A intimidade e a vida privada como expressões da liberdade humana. Porto Alegre: Núria Fabris, 2011.

AHMAD, R. B. R. Identidade genética e exame de DNA. Curitiba: Juruá, 2009.

BARBOSA, R. Novas Tecnologias Reprodutivas Conceptivas: produzindo classes distintas de mulheres? In: GROSSI, M. et al. (Orgs.). Novas tecnologias reprodutivas conceptivas: questões e desafios. Brasília: Letras Livres, 2003. p. $41-52$.

BERGEL, S. D. Los Derechos Humanos entre la Bioética y la Genética. In: Acta Bioethica, ano VIII, n. 2, p. 315-331, 2002. Disponível em: <http://www. scielo.cl/scielo.php?pid=S1726-569X2002000200011\&script $=$ sci_arttext $>$. Acesso em: 11 fev. 2015.

BRASIL, Conselho Federal de Medicina. Resolução 2.013, de 16 de abril de 2013. Adota as normas éticas para a utilização das técnicas de reprodução assistida, anexas à presente resolução, como dispositivo deontológico a ser seguido pelos médicos e revoga a Resolução CFM n⿳o 1.957/10. Publicado no Diário Oficial da União em 9/5/2013 - seção 1 - p. 119.

CANARIS, C. W. Direitos fundamentais e direito privado. Lisboa: Almedina, 2003.

CAVALCANTE FILHO, J. T. Teoria Geral dos Direitos Fundamentais. Disponível em: <http://www.stf.jus.br/repositorio/cms/portalTvJustica/portalTvJusticaNoticia/anexo/Joao_Trindadade_Teoria_Geral_dos_direitos_funda mentais.pdf $>$. Acesso em: 2 jan. 2015.

COTTO, Mayra Carillo. Nuevos metodos de concepción humana: estúdio sobre sus consecuencias en el ordenamento juridico puertorriqueño. Revista Juridica de La Universidad de Puerto Rico, Rio Piedras, v. 56, n. 1, p. 127-157, 1987.

DIMOULIS, D.; MARTINS, L. Teoria Geral dos Direitos Fundamentais. 5. ed. São Paulo: Atlas, 2014. 
FERNANDES, Silvia da Cunha. As técnicas de reprodução humana assistida e a necessidade de sua regulamentação jurídica. Rio de Janeiro: Renovar, 2005. FERRAZ, A. C. B. B. C. Reprodução humana assistida e suas consequências nas relações de família. Curitiba: Juruá, 2011.

FRASER, R. T. D.; LIMA, I. M. S. O. Intersexualidade e direito à identidade: uma discussão sobre o assentamento civil de crianças intersexuadas. In: Journal of Human Growth and Development, v. 22, n. 3, p. 358-366, 2012.

HAMMERSCHMIDT, D. Intimidade genética e direito da personalidade. Curitiba: Juruá, 2013.

LEITE, Eduardo de Oliveira. Procriações artificiais e o direito: aspectos médicos, religiosos, psicológicos, éticos e jurídicos. São Paulo: Revista dos Tribunais, 1995.

MAIA, R. Da horizontalização dos Direitos Fundamentais. In: Revista da Faculdade de Direito do Sul de Minas, ed. especial, 2008. p. 107-126. Disponível em: <http://www.fdsm.edu.br/site/posgraduacao/volumeespecial/08.pdf>. Acesso em: 2 jan. 2015.

MASSINI, C. I. Los Derechos Humanos y La Constitución Argentina Reformada: Consideraciones en ocasión de un aniversario. In: Persona y Derecho, Navarra, n. 58, p. 71-103, 2008.

OMMATI, J. E. M. As novas técnicas de reprodução à luz dos princípios constitucionais. In: Revista de Informação Legislativa, Brasília, ano 36, n. 141, p. 229-238. 1999. Disponível em: <http://www2.senado.leg.br/bdsf/bit stream/ handle/id/464/r141-17.pdf >. Acesso em: 19 nov. 2014.

PETTERLE, S. R. O direito fundamental à identidade genética na Constituição Brasileira. Porto Alegre: Livraria do Advogado, 2007.

PFAFFENSELLER, M. Teoria dos Direitos Fundamentais. In: Revista Jurídica, Brasília, v. 9, n. 85, p. 92-107, jun./jul. 2007. Disponível em: <http://www. planalto.gov.br/ccivil_03/revista/Rev_85/Artigos/PDF/MichelliPfaffenseller_Rev85.pdf $>$. Acesso em: 2 jan. 2015. 
ROULAND, N. Nos confins do Direito: antropologia jurídica da modernidade. São Paulo: Martins Fontes, 2003.

SCARPARO, M. S. Fertilização assistida: questão aberta: aspectos científicos e legais. Rio de Janeiro: Forense Universitária, 1991.

WEIDER, R. Reprodução assistida: aspectos do biodireito e da bioética. Rio de Janeiro: Lumen Juris, 2007.

Recebido em: 29/6/2015

Revisões requeridas em: 28/7/2015

Aceito em: 30/7/2015 